\title{
DESCRIBING THE MOUNTAINSNAILS (OREOHELIX SP.) OF Grand TETON NATIONAL PARK, WYOMING
}

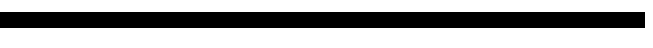 \\ LUSHA TRONSTAD $\uparrow$ GARY BEAUVAIS $\uparrow$ UNIVERSITY OF WYOMING $\uparrow$ LARAMIE, WY \\ JEANNE SERB $\uparrow$ KEVIN ROE $\uparrow$ IOWA STATE UNIVERSITY $\uparrow$ AMES, IA
}

$\uparrow$

\section{$\uparrow \quad$ ABSTRACT}

Invertebrates are receiving an increasing amount of conservation attention across North America. Currently, about $40 \%$ of the animals listed under the U.S. Endangered Species Act (ESA) are invertebrates (www.NatureServe.org). The National Park Service and other agencies require better information on invertebrate faunas in order to effectively conserve this important group of animals. One way to prioritize invertebrate groups for study is to assess the number of rare taxa within a given genus. In this context, Oreohelix (mountainsnails) are a top priority because the genus is assumed to support a very high percentage of rare and endemic taxa. Additionally, Oreohelix species in Wyoming and surrounding states have been petitioned for ESA listing in the recent past. The diversity of Oreohelix forms in Wyoming is not wellunderstood, and the current taxonomy may not reflect the true pattern of diversity within the state. Therefore, we are studying both the morphology and genetic structure of Oreohelix in Grand Teton National Park to begin to understand the diversity of mountainsnails in the state. We collected Oreohelix from 4 locations in Grand Teton National Park. Based on shell and internal characteristics, all individuals were identified as O. subrudis. We are currently preparing specimens for DNA sequencing.

\section{$\downarrow \quad$ INTRODUCTION}

Invertebrates compose $99 \%$ of the animals on earth (Ponder and Lunney 1999). Despite the fact that most animals lack a backbone, far less is known about invertebrates than their vertebrate counterparts.
Non-marine mollusks are a diverse group of invertebrates composed of terrestrial and freshwater snails and bivalves, and these animals are one of the most critically impaired groups on earth (Lydeard et al. 2004). Unfortunately, the highest number of recorded extinctions has occurred within the mollusk group. About 24,000 terrestrial mollusks are described, and an estimated 11,000 to 40,000 terrestrial mollusks are currently undescribed (Lydeard et al. 2004). Of the described species, 1,222 (5\%) were on the 2002 International Union for Conservation of Nature Red List of Threatened Species (www.redlist.org, Lydeard et al. 2004).

Land snails are particularly threatened because of several life history traits. First, snails move small distances each year, making dispersal extremely limited (Overton et al. 2009). Because few individuals immigrate to new colonies, gene flow among neighboring populations is probably limited. These reasons likely promote the formation of locallyendemic forms. Second, climate change may have the greatest effect on high elevation species, such as snails in the genus Oreohelix (mountainsnails). Species may shift their ranges as climate warms; however, species that live at high elevations may be in jeopardy as they will have less area at higher elevations to move (Muller et al. 2009).

Oreohelix are charismatic land snails that are understudied, despite being easily observed (10-20 $\mathrm{mm}$ diameter). The lifespan of these snails is unknown. They carry their young internally (ovoviviparous) and juvenile snails are born at $\sim 2.5$ whorls, which is unique among snails (Anderson et al. 2007). In the food web, Oreohelix play a fundamental 
role by consuming organic matter (Speiser 2001). These snails are also food for many animals, such as birds, small mammals, and reptiles.

Snails in the genus Oreohelix are generally considered rare, and their taxonomy is in desperate need of revision. NatureServe lists 80 species or subspecies of Oreohelix in North America, of which $47(60 \%)$ are considered imperiled or critically imperiled (www.NatureServe.org). Furthermore, several Oreohelix snails have been proposed for listing under the ESA, including Oreohelix strigosa cooperi endemic to the Black Hills, Oreohelix carinifera known from Montana and possibly Wyoming, and Oreohelix pygmaea in the Bighorn Mountains of Wyoming and Montana. If these snails are to be protected, we must first understand their diversity and distribution. Many land snails were initially identified using shell characteristics, but shells can vary widely and are not a reliable means of identifying Oreohelix (Pilsbry 1916). The last revision of the genus was done in 1939 and many of the species were based on shell morphology (Pilsbry 1939). A revision of the Oreohelix genus is needed to understand what taxa are unique and which are widespread. In order to revise the genus, dissections and DNA sequencing should be done together. The objective of the project was to collect Oreohelix within Grand Teton National Park, measure morphological characteristics, and sequence their DNA to understand what species live in the park. Additionally, the project will help resolve taxonomic issues within Wyoming and the western United States where these snails are found. This project is part of a larger effort by the Wyoming Natural Diversity Database to understand the diversity of Oreohelix in Wyoming.

\section{$\uparrow \quad$ METHODS}

We hiked to areas with known Oreohelix populations in Grand Teton National Park (L. Tronstad, personal observation) and surveyed other areas with suitable habitat. We collected $\sim 10$ individuals from each observed population segment. Snails were drowned in water for 24-36 hours so that the foot protruded from the shell for dissection. After that time, we increased ethanol concentration over 3 days to a final concentration of $80 \%$ to preserve the snails and their DNA. In the laboratory, we identified Oreohelix using the available key (Pilsbry 1939) and recent studies (e.g., Weaver et al. 2006, Chak 2007). We measured morphology that is pertinent to Oreohelix identification, including both shell (diameter, height, umbilicus diameter, whorls, number of bands, height to width ratio, umbilicus ratio) and internal characteristics (penis length, ribbed penis length, number of penis ribs, ribbed penis ratio, and noted any swollen areas). Shell characteristics were measured with digital calibers and internal characteristics were measured with a calibrated ocular micrometer in a dissecting microscope. The ribbed penis ratio was calculated as the length of the penis that was ribbed divided by the total penis length. The umbilicus ratio is the diameter of the umbilicus divided by the diameter of the shell. We are currently preparing specimens for DNA sequencing.

\section{$\downarrow \quad$ PRELIMINARY RESULTS}

We collected 36 Oreohelix specimens from 4 areas in Grand Teton National Park (Granite Creek, Ditch Creek, Moose Creek, and Owl Creek; Figure 1). These areas had calcium in the bedrock (e.g., limestone), which is needed to build their shells.

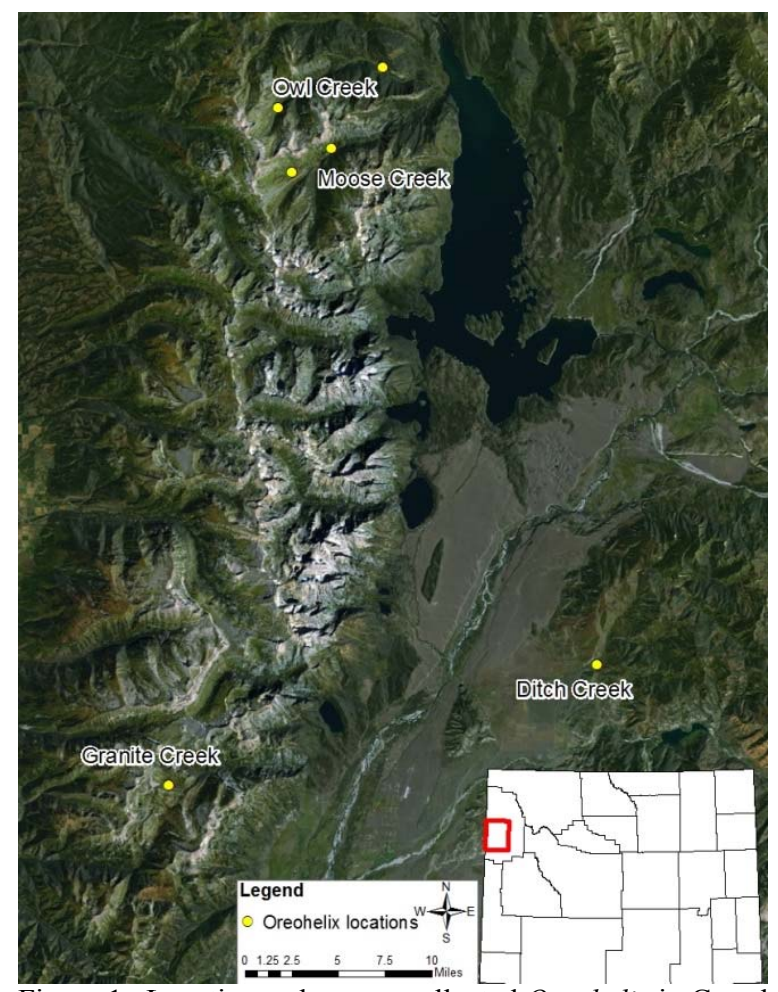

Figure 1. Locations where we collected Oreohelix in Grand Teton National Park. We collected snails at 2 locations in both Owl and Moose Creeks. The inset map shows the location of the map in Wyoming.

All the individuals we collected best matched the description of Oreohelix subrudis (subalpine mountainsnail). Pilsbry (1939) described O. subrudis as having shells $14-21 \mathrm{~mm}$ in diameter, $\sim 11 \mathrm{~mm}$ in height, and the diameter of the umbilicus is $\sim 1 / 3$ of the shell's width (Table 1). Pilsbry (1939) reported that 
most individuals had 2 bands on their shell. We observed that most individuals from the park had 2 brown bands and some individuals had additional small bands on their shells. Characteristics of some individuals from Granite Creek were smaller because several of the individuals we collected were juveniles ( $<5$ shell whorls). Pilsbry (1939) described the internal characteristics of $O$. subrudis as having a mean ribbed penis ratio of $\sim 0.50$ and having 4 or 6 ribs on the penis (Table 2). Additionally, the median portion of the penis was swollen on most of the individuals we dissected which is a unique characteristic of O. subrudis (Pilsbry 1939).

Table 1. Mean shell characteristics of Oreohelix from 4 areas of Grand Teton National Park.

\begin{tabular}{|c|c|c|c|c|}
\hline Site & Ditch & Granite & Moose & Owl \\
\hline Diameter (mm) & 19.5 & 16.6 & 18.9 & 20.4 \\
\hline Height (mm) & 12.0 & 8.8 & 10.7 & 11.7 \\
\hline Height/Diameter ratio & 0.61 & 0.53 & 0.57 & 0.58 \\
\hline Umbilicus (mm) & 3.5 & 3.3 & 3.5 & 4.1 \\
\hline Umbilicus ratio & 0.18 & 0.20 & 0.19 & 0.20 \\
\hline Whorls & 5.1 & 4.6 & 5.0 & 5.1 \\
\hline Bands & 4.3 & 2.2 & 4.8 & 2.0 \\
\hline
\end{tabular}

Table 2. Mean internal characteristics of Oreohelix from 4 areas of Grand Teton National Park.

\begin{tabular}{|l|rrrr|}
\hline Site & Ditch & Granite & Moose & Owl \\
\hline Penis length $(\mathrm{mm})$ & 10.4 & 6.0 & 9.4 & 10.4 \\
Ribbed penis length $(\mathrm{mm})$ & 5.7 & 6.3 & 5.1 & 5.5 \\
Ribbed penis ratio & 0.54 & 0.63 & 0.54 & 0.52 \\
Number of penis ribs & 6 & 4 & 6 & 5 \\
\hline
\end{tabular}

\section{$\downarrow \quad$ MANAGEMENT IMPLICATIONS}

According to current taxonomy, Oreohelix subrudis is one of the most widespread species within the genus. O. subrudis ranges from British Columbia to New Mexico and from Washington to Wyoming. $O$. subrudis is considered vulnerable in British Columbia, Utah, and New Mexico, and secure in Montana (not ranked in other states and provinces; www.NatureServe.org). In Wyoming, we have collected O. subrudis from the Bighorn Mountains near Ten Sleep, Heart Mountain north of Cody (Tronstad 2011), and the Gardner Mountain Wilderness Study Area west of Kaycee (Estes-Zumpf et al. 2014). Pilsbry (1939) reported O. subrudis from Mammoth in Yellowstone National Park. DNA sequencing from individuals collected from Grand Teton National Park will help resolve taxonomic issues within the mountainsnails.
Of the 80 Oreohelix taxa currently recognized, many are assumed to be endemic to a single locale (www.NatureServe.org). These assumptions have led to 27 taxa (34\%) being recently petitioned for ESA listing, including 3 Oreohelix taxa in Wyoming. Such listing petitions will likely increase in frequency. Currently, about $40 \%$ of ESA-listed animals in the U.S. are invertebrates. In Wyoming, 13 invertebrates have been petitioned for listing, all within the past 8 years. Twenty invertebrates are listed under the ESA in adjacent states, with 7 of those taxa being listed in the past 10 years and 16 of those taxa listed in the past 22 years. The trend is clearly towards more invertebrate animals being petitioned for, and granted, ESA protection in the western U.S., and Oreohelix taxa are prime targets. The paucity of basic information regarding actual species and subspecies diversity substantially complicates management and policy decisions such as ESA listing, recovery, and delisting. This is a debate that needs to be informed by objective science. The regulatory implications of ESA listing are alone severe enough to justify targeted research to delimit species and distributions within Oreohelix.

\section{ACKNOWLEDGEMENTS}

We thank Don and Lusha Alzner for assisting with snail collection, and Bryan Tronstad for both field and laboratory assistance.

\section{LITERATURE CITED}

Anderson, T. K., K. F. Weaver, and R. P. Guralnick. 2007. Variation in adult shell morphology and life-history traits in the land snail Oreohelix cooperi in relation to biotic and abiotic factors. Journal of Molluscan Studies 73(2): 129-137.

Chak, T. C. S. 2007. Phylogenetic relationships and population differentiation of Oreohelix landsnails in Wyoming and adjacent South Dakota. University of Wyoming.

Estes-Zumpf, W., L. Tronstadt, L. Abernathy, D. Keinath, J. Handley, and J. Walker. 2014. Inventory and monitoring of sensitive species in the Gardner Mountain Wilderness study area, Wyoming. Wyoming Natural Diversity Database, Laramie, WY.

Lydeard, C., R. H. Cowie, W. F. Ponder, A. E. Bogan, P. Bouchet, S. A. Clark, and F. G. Thompson. 2004. The global decline of nonmarine mollusks. BioScience 54(4): 321-330. 
Müller, J., C. Bassler, C. Stratz, B. Klocking, and R. Brandl. 2009. Molluscs and climate warming in a low mountain range national park. Malacologia 51(1): 89-109.

Overton, J., G. M. Barker, and R. Price. 2009. Estimating and conserving patterns of invertebrate diversity: A test case of New Zealand land snails. Diversity and Distributions 15(5): 731-741.

Pilsbry, H. A. 1916. Notes on the anatomy of Oreohelix, with a catalogue of the species. Proceedings of the Academy of Natural Sciences of Philadelphia, 340-359.

Pilsbry, H. A. 1939. Land mollusca of North America: (north of Mexico). Academy of Natural Sciences.
Ponder, W. F., G. A. Carter, P. Flemons, and R. R. Chapman. 2001. Evaluation of museum collection data for use in biodiversity assessment. Conservation Biology 15(3): 648-657.

Speiser, B., and G. M. Barker. 2001. Food and feeding behaviour. The Biology of Terrestrial Mollusks, 259-288.

Tronstad. L. 2011. Oreohelix land snails of Heart Mountain Ranch and Tensleep Preserve, WY.

Weaver, K. F., T. Anderson, and R. Guralnick. 2006. Combining phylogenetic and ecological niche modeling approaches to determine distribution and historical biogeography of Black Hills mountain snails (Oriohelicidae). Diversity and Distribution 12(6): 756-766. 